\title{
Gender Budgeting as a Means to Implement the Maputo Protocol's Obligations to Provide Budgetary Resources to Realise Women's Human Rights in Africa
}

\author{
Ashwanee Budoo \\ Dr.; Centre for Human Rights, University of Pretoria \\ sheetal6189@yahoo.com
}

\begin{abstract}
Articles 4(2)(i), 10(3) and 26(2) of the Protocol to the African Charter on Human and Peoples' Rights on the Rights of Women in Africa (Maputo Protocol) impose an obligation on states to provide sufficient budgetary resources to realise women's human rights. Despite the fact that several African countries have ratified the Maputo Protocol, there is still insufficient budgetary allocation to realise women's human rights. This article presents gender budgeting as a step that African states can take towards the provision of sufficient resources to realise women's human rights. It studies the concept of gender budgeting and its objectives to demonstrate the link between gender budgeting and the provision of budgetary resources to realise women's human rights. It also studies the challenges that states face in the adoption of gender budgeting and concludes that despite the fact that there are challenges, they can be overcome if states show the required will to do so.
\end{abstract}

\section{Keywords}

gender budgeting - Maputo Protocol - provision of budgetary resources to realise women's human rights

* This article is part of the author's LLD thesis submitted at the Faculty of Law, University of Pretoria.

** Programme Manager of the LLM/MPhil in Human Rights and Democratisation in Africa programme at the Centre for Human Rights, Faculty of Law, University of Pretoria. 
The plight of women in Africa has been categorised as 'shocking.' ${ }^{1}$ Despite the fact that men and women are both human beings, women face more vulnerabilities. Inequality on the basis of gender 'is entrenched in all societal structures' of the region. ${ }^{2}$ The idea that women are inferior to men is woven into the society. ${ }^{3}$ Africa is a continent that still faces the challenges of poverty and armed conflicts. Consequently women in Africa suffer since the above vulnerabilities, together with 'retrogressive cultural practices and traditions', undermine women's human rights. ${ }^{4}$ Women in Africa have been victims of specific situations that act as challenges for the realisation of their human rights. ${ }^{5}$

Recognising that women face vulnerabilities, article $4(\mathrm{l})$ of the Constitutive Act of the African Union ${ }^{6}$ (AU) establishes the 'promotion of gender equality' as one of the principles according to which the AU should function. This implies that at the time of the establishment of the AU, African countries acknowledged that men and women are treated differently across the continent and that the regional human rights system should give attention to the phenomenon of gender inequality.

As a concrete step to ensure that women are afforded the protection that they are entitled to, the Protocol to the African Charter on Human and Peoples' Rights on the Rights of Women in Africa ${ }^{7}$ (Maputo Protocol) was adopted in 2003. There was a need for the Maputo Protocol since there was little consideration given to existing women's human rights standards on the continent. ${ }^{8}$ This protocol has been described as a 'pioneering and legally binding instrument, which marks a new beginning in the promotion and protection of women's

1 P Burnett, S Karmali and FM Manji, 'Introduction' P Burnett, S Karmali and FM Manji (eds), Grace, Tenacity and Eloquence: The Struggle for Women's Rights in Africa (Fahamu Publishers, Oxford 2007) 1-2.

2 K Stefiszyn, 'The African Union: Challenges and Opportunities for Women' (2005) 5 AHRLJ $35^{8}$.

3 Ibid.

4 C Ageng'o, 'International Women's Day - Can we dare celebrate?' in Burnett and others (n 1) 6.

5 G Mutukwa, 'Home-grown Rights Instruments: Supporting the Protocol on the Rights of Women in Africa' in Burnett and others (n 1 ) 18.

6 Adopted by African Heads of State in 2000, entered into force in 2001.

7 Adopted on 11 July 2003, entered into force on 25 November 2005.

8 F Banda, 'Protocol to the African Charter on the Rights of Women in Africa' in M Evans and R Murray (eds), The African Charter on Human and Peoples' Rights: The System in Practice, 1986-2006 (2nd edn Cambridge University Press, Cambridge 2008) 445. 
human rights on the African continent'. ${ }^{9}$ The instrument is expected to accelerate the eradication of women's human rights violations on the continent. It can be considered as an expression of the AU's commitment to put women's human rights in the forefront.

However, ratifying or domesticating a legal instrument does not automatically lead to the realisation of the rights therein. A proper implementation of the Maputo Protocol at the domestic level necessitates 'strategies to engage with resource mobilisation, allocation and tracking.' ${ }^{10}$ Appreciating that resources are needed for the implementation of rights, the Maputo Protocol 'enshrines provisions expressly providing for duties for resource allocation and even of budgetary arrangement'.11 The provisions of the Maputo Protocol that provide for budgetary allocation prove that the framers recognised that implementation of the rights in the Maputo Protocol required resources. Nevertheless, despite these provisions, women's human rights continue to be violated across the continent.

According to the 2014 Gender Inequality Index of the United Nations Development Programme (UNDP), ${ }^{12}$ African countries are ranked low in terms of women's human rights. ${ }^{13}$ No African countries offers a very high human development for women and about four are categorised as states that provide high human development for women with the majority falling in the category of either medium or low human development for women..$^{14}$

9 C Ocran, 'Recent Developments-Actualities: The Protocol to the African Charter on Human and Peoples' Rights on the Rights of Women in Africa' (2007) 15 AJICL 147.

10 M Rusimbi, 'Financing the Protocol: Considerations for Influencing Budgets from Experiences in Tanzania' in R Musa, FJ Mohammed and FM Manji (eds), Breathing Life into The African Union Protocol on Women's Rights in Africa (Solidarity for African Women's Rights, Nairobi 2006) 38 .

SA Yeshanew, The Justiciability of Economic, Social and Cultural Rights in the African Regional Human Rights System (Intersentia, Cambridge 2013) 262.

12 UNDP, 'Gender Inequality Index': The Gender Inequality Index 'measures gender inequalities in three important aspects of human development - reproductive health measured by maternal mortality ratio and adolescent birth rates; empowerment, measured by proportion of parliamentary seats occupied by females and proportion of adult females and males aged 25 years and older with at least some secondary education; and economic status expressed as labour market participation and measured by labour force participation rate of female and male populations aged 15 years and older' < http://hdr.undp.org/ en/content/gender-inequality-index-gii > accessed 7 October 2016. .undp.org/en/content/table-4-gender-inequality-index> accessed 7 October 2016. UNDP Ibid: The four countries are Mauritius, Seychelles, Tunisia and Algeria. 
Since most African countries offer a low human development for women, it can be deduced that gender inequality is still a harsh reality of the continent. Most societies continue to subject African women to numerous vulnerabilities in different spheres including in: ${ }^{15}$ conflict situations; peace-keeping and refugee status; political representation; education and literacy; economic activity and employment; sexual and reproductive health; human immunodeficiency virus infection and acquired immune deficiency syndrome; and trafficking. Such vulnerabilities, in addition to others, are addressed in the Maputo Protocol that recognises that there is a need for budgetary allocations to realise the rights therein.

As at May 2017, 38 out of 55 African countries had ratified the Maputo Protocol since its entry into force. ${ }^{16} \mathrm{~A}$ situational analysis of women's human rights in the ratifying states reveals that all of them still face challenges in implementing the provisions of the Maputo Protocol. Amongst the provisions are those that relate to budgetary allocations to realise women's human rights.

This article proposes the adoption of gender budgeting in order to implement the budgetary allocation provisions of the Maputo Protocol. The concept of gender budgeting is not foreign to global and regional human rights law. The United Nations (UN) has encouraged countries to adopt gender budgeting on several occasions. The Beijing Platform for Action for Equality, Development and Peace 1995 (Beijing Platform for Action), for instance, requires countries to integrate 'a gender perspective in budgetary decisions on policies and programmes, as well as the adequate financing of specific programmes for securing equality between women and men.17 It further states that the implementation of the Beijing Platform for Action necessitates the adjustment of 'budgets to ensure equality of access to public sector expenditures' and the allocation of 'sufficient resources, including resources for gender-impact analysis'. ${ }^{18}$ Since gender budgeting is intended to take into consideration budgetary allocations for women, this article assesses the adoption of gender budgeting as a means to implement the budgetary allocation provisions of the Maputo Protocol. It

\footnotetext{
15 K Kemp, 'General Situation of Women in Africa' in Musa and others (n 10) 3-8.

$16 \mathrm{AU}$, 'List of countries which have signed, ratified/acceded the Protocol to the African Charter on Human and Peoples' Rights on the Rights of Women in Africa (1 April 2016) $<$ http://www.au.int/en/sites/default/files/treaties/7783-sl-protocol_to_the_african_ charter_on_human_and_peoples_rights_on_the_rights_of_women_in_africa_12.pdf> accessed 8 June 2016; Algeria deposited its ratification documents in January 2017 and became the 38 th country that ratified the Maputo Protocol.

17 Paragraph 345 of the Beijing Platform for Action <http://www.un.org/womenwatch/daw/ beijing/platform/plat2.htm > accessed 8 October 2014 .

18 Paragraph 346 of the Beijing Platform for Action.
} 
firstly expands on the different articles of the Maputo Protocol that make reference to budgetary provision. Secondly, it elaborates on the concept and on the objectives of gender budgeting, while highlighting the challenges in the adoption of gender budgeting. Third, it provides for a conclusion.

\section{The Maputo Protocol and the Obligation to Provide Budgetary Resources to Realise Women's Human Rights}

At the global level, the treaties of the United Nations (UN) make reference to 'maximum available resources', 'necessary measures', 'appropriate measures', and 'necessary steps' without expressly mentioning budgetary allocation of resources. The provisions of the treaties have later been interpreted by treaty monitoring bodies to include budgetary allocation of resources in the steps that states must take to realise the rights protected by the treaty.

At the regional level, while the African Charter on Human and Peoples' Rights (African Charter) and the African Charter on the Rights and Welfare of the Child (African Children's Charter) impose an obligation to generally 'adopt legislative or other measures' to give effect to their provisions, ${ }^{19}$ the Maputo Protocol 'enshrines provisions expressly providing for duties for resource allocation and even of budgetary arrangement' to realise women's human rights. ${ }^{20}$ This 'does not have the form of typical human rights provisions that govern the relationship between states and individuals.' ${ }^{21}$

The current section unpacks those provisions of the Maputo Protocol which impose an obligation on states to provide budgetary resources to realise women's human rights. It studies articles 26(2), 4(2)(i) and 10(3) of the Maputo Protocol with the view of establishing that African states have the obligation to provide budgetary resources to realise women's human rights.

19 Article 1 of the African Charter: 'The Member States of the Organization of African Unity parties to the present Charter shall recognize the rights, duties and freedoms enshrined in this Chapter and shall undertake to adopt legislative or other measures to give effect to them.'; Article 1.1 of the African Children Charter: Member States of the Organization of African Unity Parties to the present Charter shall recognize the rights, freedoms and duties enshrined in this Charter and shall undertake to the necessary steps, in accordance with their Constitutional processes and with the provisions of the present Charter, to adopt such legislative or other measures as may be necessary to give effect to the provisions of this Charter.'

20 Yeshanew (n 11$) 262$.

21 Ibid. 


\subsection{Article 26(2) of the Maputo Protocol}

Article 26(2) of the Maputo Protocol provides for a broader budgetary reconstruction in order to give effect to the rights protected by the instrument. ${ }^{22}$ More specifically, it provides that 'States Parties undertake to adopt all necessary measures and in particular shall provide budgetary and other resources for the full and effective implementation of the rights herein recognised'.

Unlike articles 4(2)(i) and 10(3) of the Maputo Protocol, ${ }^{23}$ the current article is broader and gives more leeway to states. It can be argued that article 26 of the Maputo Protocol is inclusive of articles 4(2)(i) and 10(3) of the instrument since 'all necessary measures' to 'provide budgetary ... resources' for the realisation of the rights protected by the Maputo Protocol includes a reduction in military expenditure, ${ }^{24}$ and also targets violence against women. Article 26 of the Maputo Protocol imposes a general obligation on states to allocate sufficient budgetary resources to realise the women's human rights protected by the Maputo Protocol.

\subsection{Article 4(2)(i) of the Maputo Protocol}

Under the rights to life, integrity and security of African women, states have the following obligation:

... take appropriate and effective measures to ... provide adequate budgetary and other resources for the implementation and monitoring of actions aimed at preventing and eradicating violence against women.

Violence against women is a form of gender-based violence which is defined as 'violence that is directed against a woman because she is a woman or that affects women disproportionately. ${ }^{25}$ The term violence against women has several manifestations which include 'violence by an intimate partner', 'rape/ sexual assault and other forms of sexual violence perpetrated by someone

Article 26(2) of the Maputo Protocol: 'States Parties undertake to adopt all necessary measures and in particular shall provide budgetary and other resources for the full and effective implementation of the rights herein recognised.'

23 Sections 2.2 and 2.3 below.

24 Yeshanew (n 11$) 294$.

25 UN Committee for the Elimination of All Forms of Discrimination against Women, 'General Recommendation No 19' in 'Note by the Secretariat, Compilation of General Comments and General Recommendations Adopted by Human Rights Treaty Bodies' (29 July 1994) UN Doc HRI/GEN/1/Rev.1 paragraph 6. 
other than a partner', 'female genital mutilation, honour killings and the trafficking of women.' ${ }^{26}$

The UN Economic Commission for Africa considered violence against women as 'the most widespread and socially tolerated of human rights violations' worldwide. ${ }^{27}$ The mention of allocation of budgetary resources in article 4(2)(i) of the Maputo Protocol may be interpreted to imply that the AU considered the lack of budgetary allocations as a challenge to combat violence against women. The inclusion of budgetary resources in article 4(2)(i) of the Maputo Protocol indicates that states have to prioritise its programmes, plans of action and policies aimed at eradicating violence against women.

However, states often put forward the argument that they do not have sufficient resources to implement the provisions of this article. ${ }^{28}$ Nevertheless, the involvement of $\operatorname{csos},{ }^{29}$ and an active and efficient judiciary can ensure that a state is abiding by its obligations under article 4(2)(ii) of the Maputo Protocol. The Zambian case of Katakwe $v$ Edward \& Others $^{30}$ can be used as an example to demonstrate the role that non-state actors have in the application of the provisions of the Maputo Protocol. In this case, the plaintiff sued the government for failing to protect her from sexual violence. The plaintiff argued that this failure on behalf of the state amounted to a violation of article 4(2)(i) of the Maputo Protocol. Nevertheless, the Court did not discuss this article while coming to its judgement. However, this case demonstrates that lawyers are aware of the existence of the provisions of the Maputo Protocol which make reference to budgetary allocations. This is a ray of hope for future cases which concern non-allocation of sufficient budgetary resources to realise women's human rights. If cases are brought to court, and jurisprudence is

26 World Health Organisation 'Global and Regional Estimates of Violence against Women: Prevalence and Health Effects of Intimate Partner Violence and Non-partner Sexual Violence' (2013) 4.

27 UN Economic Commission for Africa, 'Violence against Women in Africa: A Situational Analysis' (undated) <http://wwwl.uneca.org/Portals/awro/Publications/21VAW\%2oin\%20 Africa-A\%2osituational\%2oanalysis.pdf> accessed 12 May 2016.

28 M Muriithi, 'An analysis of the Protocol to the African Charter on Human and Peoples' Rights on the Rights of Women in Africa' in B Kombo, R Sow and FJ Mohamed, 'Journey to equality: 10 years of the Protocol on the Rights of Women in Africa' (2013) $44<\mathrm{http}$ ://www .equalitynow.org/sites/default/files/MaputoProtocol_JourneytoEquality.pdf> accessed 31 August 2015 .

29 As above.

30 Rosaria Mashita Katakwe v Edward Hakasenke \& Others Zambian High Court 30 June 2008 2006/HP/0327 <http://www.equalitynow.org/sites/default/files/zambia_high_court_ judgment.pdf $>$ accessed 31 August 2015 . 
established, states are more likely to consider resource allocation for women's human rights in their future budgets.

Article 4(2)(i) of the Maputo Protocol therefore relies on budgetary allocation of resources to eradicate violence against women. It seeks to transform the dynamics of violence against women and recognises that such a transformation is not possible without sufficient budgetary resource allocation.

\subsection{Article 1o(3) of the Maputo Protocol}

Article 10(3) of the Maputo Protocol imposes on states the obligation to 'take the necessary measures to reduce military expenditure significantly in favour of spending on social development in general, and the promotion of women in particular'. The uniqueness of article 10(3) of the Maputo Protocol is that it explicitly directs states to have a budget restructuring in favour of social development and the promotion of women. It has been highlighted that the current provision has been inserted to ensure a better realisation of socio-economic rights across Africa. ${ }^{31}$

The classification of priority in terms of expenditure is unique to article 10(3) of the Maputo Protocol and it has been considered as a 'radical departure from existing human rights norms.' ${ }^{32}$ It provides for a 'hierarchy' in terms of budgetary expenditure ${ }^{33}$ and considers expenditure on social development more important than expenditure on military. Giacca has stated that article 10(3) of the Maputo Protocol, in addition to article 26 of the Maputo Protocol, can be interpreted to mean that states have to construct their budget in a manner that realises all the rights in the Maputo Protocol. ${ }^{34}$ This argument might be motivated by the fact that social development and the promotion of the human rights of women affect all articles provided by the Maputo Protocol.

Furthermore, as highlighted by Yeshanew, in case of non-respect of article 10(3) of the Maputo Protocol, there can be 'judicial or quasi-judicial enforcement' and this might create the 'risk' that there is impeachment upon 'the legislative or executive terrain of governance. ${ }^{35}$ According to him, once a country has ratified the Maputo Protocol, it can be considered as it giving consent to the issue of monitoring organs to interfere into the way it deals with its budget. ${ }^{36}$ Article 10(3) of the Maputo Protocol therefore allows the African Commission

31 G Giacca, Economic, Social and Cultural Rights in Armed Conflict (Oxford University Press, Oxford 2014) 50 .

32 Ibid.

33 Ibid.

34 Ibid.

35 Yeshanew (n 11$) 263$.

36 Ibid. 
or the African Court to review the state budget in a continent which is full of incidences where leaders have misallocated state resources. ${ }^{37}$ If there is a strong will on behalf of the African Commission or the African Court, article 10(3) of the Maputo Protocol can be used to hold many countries responsible for misallocation of their budgetary resources.

This article indicates that African countries agree to reduce their military expenditure to promote the rights of women. It can be considered as making a 'policy prescription for states to reduce military expenditure and channel the proceeds to social spending'. ${ }^{38}$ States therefore undertake to ensure that their future budgets reflect a reduction in military expenditure in favour of social development and the promotion of women.

The above three articles of the Maputo Protocol therefore imposes an obligation on ratifying states to provide sufficient budgetary resources to realise women's human rights. However, despite the fact that 37 African states have ratified the Maputo Protocol, women across Africa still suffer human rights violations due to insufficient budgetary resources. This article identifies gender budgeting as a means for states to implement their obligation to provide resources to realise women's human rights. The following section expands on the concept of gender budgeting and its role in ensuring that states implement the budgetary allocation provisions of the Maputo Protocol.

\section{Gender Budgeting to Implement the Budgetary Allocation} Provisions of the Maputo Protocol

Many scholars and institutions have defined gender budgeting and what it entails. For the purposes of this article, the definition proposed by the Council of Europe will be used since it is one that covers the key features of gender budgeting and one that is simple to understand. The Council of Europe defines gender budgeting as follows: ${ }^{39}$

... an application of gender mainstreaming in the budgetary process. It means a gender-based assessment of budgets, incorporating a gender perspective at all levels of the budgetary process and restructuring revenues and expenditures in order to promote gender equality.

37 Giacca (n 31) 50.

$38 \quad$ Yeshanew (n 11) 291.

39 Council of Europe, 'Gender Budgeting: Conceptual Framework, Methodology and Presentation of Good Practices' (2005) 10. 
Gender budgeting basically assesses the manner in which governments' revenues and expenditures affect 'women and men, girls and boys'. ${ }^{40}$ It encompasses everyone without any discrimination, is inclusive of women and recognises that there is a deficiency in the way there is provision of budgetary resources for women. It assesses the public budgeting process from a gender lens in order to ensure that resources are efficiently allocated to realise women's human rights. ${ }^{41}$ Thus, the gender budgeting process aims at ensuring that women's human rights are considered in the public budgeting process. Gender budgeting therefore enables states to provide budgetary resources to realise the rights in the Maputo Protocol.

Gender inequality has a domino effect on all members of the society since it shows inefficiency on behalf of the government. ${ }^{42}$ Empowering women has the effect of providing countries with the possibility of a 'combination of increased productivity, improved human resources, less stress and better overall health.'43 There is an assumption that economic growth has a 'trickle down' effect on the human rights of the individuals in the society. ${ }^{44}$ However, the effect of economic growth on human rights is not direct and the state has to address each issue individually. 45

Development in Africa is in the hands of men who are at the head of the state or at the head of the family. ${ }^{46}$ Howard has pointed out that women's human rights cannot be realised unless there are reforms within a country, including the economic sphere. ${ }^{47}$ She finds it preoccupying that women's status

40 D Budlender and G Hewitt, 'Engendering Budgets: A Practitioner's Guide to Understanding and Implementing Gender-Responsive Budgets' (2003) $7<$ http://www.international budget.org/wp-content/uploads/2011/o1/Engendering_Budgets_final_doc.pdf> accessed 11 August 2016.

41 Council of Europe, 'Gender Budgeting: Final Report of the Group of Specialists on Gender Budgeting' (2005) 10 <http://www.coe.int/t/dghl/standardsetting/equality/o3themes/ gender-mainstreaming/EG-S-GB(2004)RAPFIN_en.pdf> accessed 7 October 2014.

42 D Elson, 'Integrating Gender into Government's Budget within a Context of Economic Reform' in D Budlender, D Elson, G Hewitt and T Mukhopadhyay (eds), Gender Budgets Make Cents: Understanding Gender Responsive Budgets (Commonwealth Secretariat, London 2002) 24.

43 Ibid.

44 Elson (n 4) 28.

45 Ibid.

46 RE Howard, 'Women's Rights and the Right to Development' in J Peters and A Wolper (eds), Women's Rights, Human Rights: International Feminist Perspectives (Routledge, New York 1995) 301.

47 Ibid. 
in the economic dimension in African countries is not given enough attention. Howard makes reference to the role of foreign aid in the protection of women's human rights but ignores the role of government's budget in furthering women's human rights. ${ }^{48}$

The expenditure aspect of fiscal policy has been identified as 'the most promising entry point for integrating a gender analysis' 49 The fiscal policy of the government comprises of revenues and public expenditures..$^{50}$ Traditionally these two are included in a national budget and this policy can influence the distribution of income. ${ }^{51}$ The national budget is considered as a good starting point to integrate gender issues in macroeconomic policies of the government since the outcomes can be better assessed than if there is an integration of gender issues in the monetary policy. ${ }^{52}$

Governments might take a 'gender-blind' approach to budgeting without realising that the implementation of the policy is not done in a 'vacuum' but rather in a society where both men and women co-exist and should be beneficiaries of the policy. ${ }^{53}$ By being 'gender-blind' some states might reinforce the inequalities that exist between men and women that is unfair in a world where there should be more redistributive fiscal policies. ${ }^{54}$ This is also against most governments' undertaking to promote gender equality. 55

The 'traditional' view of the budget is that it should be 'free from value and which benefits all members of the public equally without any distinction', ${ }^{56}$ However, a number of human rights approaches to budgeting have been initiated in the past years with gender budgeting gaining 'considerable momentum' ${ }^{57}$

\footnotetext{
48 Howard (n 46) 309.

49 Ibid.

50 Executive summary of IMF Policy Paper, 'Fiscal Policy and Income Inequality' (2014) <http://www.imf.org/external/np/pp/eng/2014/o12314.pdf> accessed 25 August 2015.

51 Ibid.

52 D Budlender, 'A Global Assessment of Gender Responsive Budget Initiatives' in D Budlender and G Hewitt (eds), Gender budgets make more cents: Country studies and good practice (Commonwealth Secretariat, London 2002) 85.

53 European Commission, 'Briefing Note: Gender Budgeting: Its Usefulness in ProgrammeBased Approaches to Aid' (2006) 8.

54 Ibid.

55 Ibid.

56 S Quinn, ‘Gender budgeting: Practical Implementation' (2008) $164<$ https://www.coe .int/t/dghl/standardsetting/equality/o3themes/gender-mainstreaming/CDEG(2008)15_ en.pdf $>$ accessed 8 September 2015 .

Quinn (n 56) 165 .
} 
This is so because gender budgeting provides for a means through which there can be more gender equality within budgets. ${ }^{58}$

Achieving gender equality has been one of the aims of different governments and gender budgeting is a 'strategy' to achieve that aim..$^{59} \mathrm{Gender}$ budgeting is a 'tool' that recognises 'underlying inequalities' and provides for a redress for them through resource allocations. ${ }^{60}$ It provides for new lenses through which the government can view its spending to promote gender equality. Gender budgeting has been identified as a means through which governments can live up to their international commitments to realise the rights of women through 'equality in the distribution, access and funding of public resources'. ${ }^{61}$

Also known as women's budget, gender budgeting was first adopted by the Australian government in $1984^{62}$ when the pilot Women's Budget Programme was launched. ${ }^{63}$ Recognising that 'neither money nor budgets are genderneutral, ${ }^{\prime}{ }^{4}$ more countries have been adopting a gender approach to budgeting. Different stakeholders in these countries such as 'governments, intergovernmental organisations, development agencies, and civil society groups' have been using gender budgeting as a 'central part of their strategy to advance gender equality' ${ }^{65}$

According to Alami, gender budgeting 'takes the debate on women's rights beyond a subjective understanding of gender equality and women's empowerment'.66 Proponents of gender equality are often faced with the dilemma that governments rarely take concrete actions to give effects to their commitments. In this event, gender budgeting 'translates demands to address

$58 \quad$ Ibid.

59 C Randzio-Plath, 'Gender Budgeting and Good Governance' in K Prestin (ed), 'Gender Budgeting and Democratic Governance: Experience from Africa and Europe' (2010) 3.

6o Bridge (Development - Gender), 'Gender and Budgets: Overview Report' (2003) 5 .

61 E Villagomez, 'Gender Responsive Budgets: Issues, Good Practices and Policy Options' (2004) 4 .

62 R Sharp and R Broomhill, 'Budgeting for Equality: The Australian Experience' (2002) 8 Feminist Economics 25, 26.

63 Ibid.

64 Ibid.

65 G Hewitt, 'The Commonwealth Secretariat: The Role of External Agencies' in D Budlender and another (n $\left.5^{2}\right) 13$.

66 N Alami, 'Institutionalizing Gender Responsive Budgeting: Lessons Learnt from UNIFEM Programmes' (2008) 3 <http://www.gender-budgets.org/joomdocuments/ other-GB-programmes/Institutionalizing\%20GB\%20_\%2opaper\%2oby\%2oAlami .pdf> accessed 6 October 2014. 
gender gaps in development and deficiencies in the achievement of women's rights into objective targets of public policy making with measurable results.' ${ }^{67}$

It is to be noted the gender budgeting is not just the development of a 'methodology' to approach the budgetary system. Alami has referred to gender budgeting as follows: 68

... a long-term process that builds national ownership and political support, develops institutional capacities for results oriented planning and budgeting and establishes public finance systems that are designed with equity and effectiveness in mind.

As such, the adoption of gender budgeting is not only a budgeting method but it is a continuous process that is aimed towards a more efficient allocation of resources towards the realisation of women's human rights. It is not a one-time exercise but has to be integral to the budgeting process.

Gender budgeting can be introduced in public budgets in two ways: ${ }^{69}$ The government can either identify one or more area(s) that can benefit from more resource allocation or it can systematically examine all the items in the budget so that they can have more gender equality. Both these approaches require the prioritisation of 'policies according to their relevance to gender' as a 'necessary first step.70

Gender budgeting can serve a better purpose if individuals external to the budgeting process can access to information relating to the budgeting process. More accountability and transparency in the budgeting process is therefore required. Spain, which has adopted a law that requires the presentation of a Gender Impact Report of the budget that is presented to the Parliament, ${ }^{71}$ can be used as an example of how transparency and accountability are central to the process.

Gender budgeting provides for various opportunities. ${ }^{72}$ For instance, it is a platform to calculate the actual amount allocated to women, men, boys and girls. It reveals the deficiencies that exist in the data concerning spending on men and women. Since the preparation of the gender budget involves different

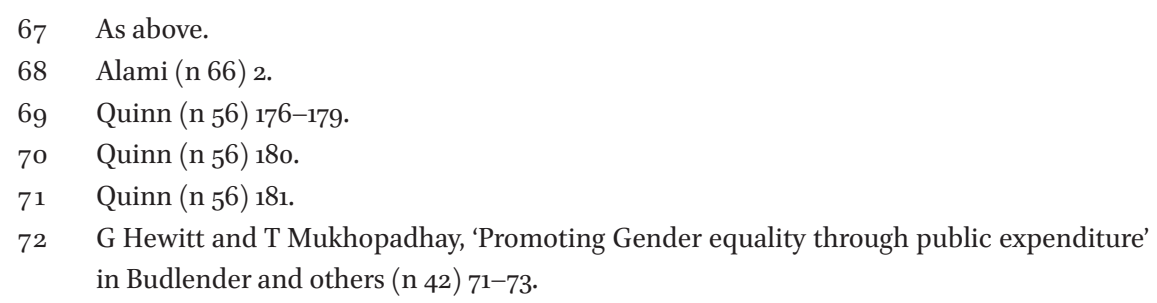


key stakeholders, it provides for an opportunity for government officials to understand the process through others. It finally reveals any discrepancies in terms of access to opportunities in the public sector by women and it has a positive impact on other social concerns.

\subsection{Objectives of Gender Budgeting}

The adoption of gender budgeting is done with the ultimate aim of realising women's human rights and is thus in line with the implementation of the obligation to provide sufficient budgetary resources towards the realisation of women's human rights. Gender budgeting has some objectives that contribute to the realisation of women's human rights. The National Commission for the Promotion of Equality in Malta (NCPE) has expanded upon these objectives of gender budgeting and they are as follows: ${ }^{73}$ Gender equality, and the respect of the principles of good governance including accountability, transparency and participation, and efficiency and effectiveness.

\subsubsection{Gender Equality}

Gender budgeting has been considered as a must to achieve gender equality. ${ }^{74}$ Mumford has pointed out that an analysis of the impact of budgetary expenditure on women 'is likely to enable clear, policy-based articulation of the importance of gender equality'. ${ }^{75}$ One of the aims of gender budgeting is the inclusion of gender equality in all the policies of the government. ${ }^{76}$ It points out to those policies and programs that do no address gender inequalities and requires the government to allocate more resources to them. Gender budgeting highlights the discrimination and inequalities in a government's budget. The adoption of gender budgeting requires states to ensure that its expenditure does not accentuate the existing discrimination against women and gender inequalities and instead assess how it should allocate its expenditure to achieve gender equality. It therefore requires the government to adopt a budget which is inclusive of policies to reduce gender inequality.

\footnotetext{
73 NCPE, 'Gender Responsive Budgeting: A Study on GRB initiatives in Sweden, Switzerland, Italy, United Kingdom and France' (2009) 15-17.

74 R Nallari and B Griffith, Gender and Macroeconomic Policy (The World Bank, Washington DC 2011) 40.

75 A Mumford, Tax Policy, Women and the Law: UK and comparative perspectives (Cambridge University Press, Cambridge 2010) 30.

$76 \quad \mathrm{NCPE}(\mathrm{n} 73) 15$.
} 


\subsubsection{Good Governance}

Good governance implies that 'rules, processes and actions are established in order for power to be exerted with the right pressure and in the right direction' ${ }^{77}$ The adoption of gender budgeting will ensure that the government is abiding by the principle of good governance since gender budgeting incorporates components such as accountability, transparency and participation, and efficiency and effectiveness.

\section{Accountability}

States often are parties to several international and regional instruments which impose an obligation on them to realise women's human rights. The Australian gender budgeting initiative recognised that the process will be a means to make 'government accountable for their gender equality commitments'.78 Assessing the government's expenditure to give effect to the rights of women is one avenue through which one can derive whether the government is giving effect to its international and regional obligations in relation to the realisation of women's human rights.

Gender budgeting is a means to review the manner in which the government is allocating its expenditure to realise women's human rights and this process is ignored in 'traditional government budgets. ${ }^{79}$ Gender budgeting assesses the impact of government's expenditure on men and women, girls and boys and therefore it is indicative of whether the government is investing sufficient amount of resources to realise women's human rights.

In addition to the above, Mumford has also identified gender budgeting as a means to hold governments responsible for pre-existing commitments. ${ }^{80}$ She highlighted that predecessors might have ratified treaties which might be ignored by governments. She pointed out that gender budgeting might be used as a mechanism to hold the government accountable for non-execution of treaty commitments by previous governments.

csos and the population can use the information contained in the gender budget to make the government explain its decisions through judicial or nonjudicial avenues in the event the government is not allocating sufficient resources towards the realisation of women's human rights. Therefore, gender budgeting aims to provide the population with information which can be used

\footnotetext{
77 NCPE (n 73) 17.

78 Sharp and another (n 62) 36 .

79 Ibid.

8o $\quad$ Mumford (n 75$) 30$.
} 
to hold the governments responsible in the event they are not abiding by their obligations to realise women's human rights.

\section{Transparency and Participation}

Access to information has been described as the lifeblood' of a democracy. ${ }^{81}$ It provides for the benchmark against which the people can evaluate the job of their representatives. If there is no access to information, the whole election process is redundant since the citizens do not have any account of what their representatives have done for them. Thus, for a democracy to function there is a need for transparency.

Transparency, being 'key' to good governance, allows the curbing down of practices of representatives to take advantage of their position and to illegitimately benefit from the revenues that should be converted into public expenditure. ${ }^{82}$ However, transparency is a controversial topic. As much as one would like to have access to all the files and documents of the government's undertaking, there is the issue of 'secrecy' where outsiders of the government are not supposed to have access to some types of information. ${ }^{83}$

The budget of a country in this case provides for a means for transparency. csos analysing the budget from a gender perspective have times and again emphasised that governments should make information about the budget public. ${ }^{84}$ African countries are usually characterised by weak transparency that 'undermine the possibility of planning and executing policies, notably those relating to structural transformation. ${ }^{85}$

Transparency being central to 'legitimate and effective governance' is important in the budget process since it demonstrates how the government, as the representative of the people, is investing the people's money for their benefit. ${ }^{86}$ The human rights analysis of budgets has acted as a catalyst for governments to make the budget public, ${ }^{87}$ thus making the process more transparent.

Gender budgeting necessitates the accuracy of government records which enables one to assess the expenditures. As a result, it has been considered as

\footnotetext{
81 AM Florini, 'Increasing Transparency in Government' (2002) 19 IJWP 3.

82 Florini (n 81) 3 .

83 Florini (n 81) 4 .

84 A Blyberg, 'The Case of the Mislaid Allocation: Economic and Social Rights and Budget Work' (2009) SUR-IJHR 123, 125 .

85 United Nations Economic Commission for Africa, 'Measuring Corruption in Africa: The International Dimension Matters' (2016) <http://www.uneca.org/sites/default/files/ PublicationFiles/agr4_eng_fin_web.pdf> accessed 25 May 2016.

86 Ibid.

87 Blyberg (n 84) 123 .
} 
a 'monitoring tool and framework for objective comparison of the developmental achievements of governments gained through public expenditure'.88 Budget analysis is a very important tool in the hands of csos which concentrate on women's human rights. Since it provides for transparency, csos can assess the gender responsiveness of the budget and assess whether enough resources have been allocated to women's human rights. In the event they find that there are available resources from other items of the budget which can be redirected towards the realisation of women's human rights, they can come up with a project that contains the policies and programmes that the government can adopt if it reallocates the resources. ${ }^{89}$

\section{Efficiency and Effectiveness}

The gender budgeting process is inclusive of assessing how government's allocations are contributing towards the realisation of women's human rights. A national budget without gender consideration tends to be inefficient and ineffective towards the realisation of women's human rights since it is ignorant of challenges that women and girls face. ${ }^{90}$

Gender budgeting allows governments to take into account the challenges that women face and adopt policies to ensure that those challenges are minimised. For instance, a gender-neutral policy on access to contraceptives is not appreciative of the fact that some societies are still male dominated and women are subjected to the whims and caprices of their partners. The resources spent on this policy will be inefficient and ineffective since there will be no programs for the sensitisation of women and men about the use of contraceptives. Gender budgeting will be inclusive of the effect that the expenditure will have on women's human rights thereby making governments' policies more efficient and effective. Similarly, taking into consideration women's human rights while budgeting will enable the government to have more efficient and effective policies.

The above objectives of gender budgeting indicate that the concept aims to ensure that government's financial resources are used optimally to realise women's human rights. Therefore, gender budgeting can be adopted by countries as a means to provide sufficient budgetary resources to realise women's

\footnotetext{
$88 \quad$ Hewitt and another (n 72$) 60$.

89 H Hofbauer, A Blyberg and W Krafchik, 'Dignity Counts: A Guide to Using Budget Analysis to Advance Human Rights' (2004) 3 <http://internationalbudget.org/wp-content/ uploads/Dignity-Counts-A-Guide-to-Using-Budget-Analysis-to-Advance-Human-RightsEnglish.pdf $>$ accessed 26 August 2014.

9o $\mathrm{NCPE}(\mathrm{n} 73) 17$.
} 
human rights. However, the adoption of gender budgeting faces some challenges. The section below studies those challenges and the ways in which they can be overcome.

\subsection{Challenges in the Adoption of Gender Budgeting}

Despite the fact that countries have been encouraged to adopt gender budgeting, countries have still not entirely integrated gender budgeting in their national budgeting processes. This section identifies the challenges that governments face to adopt gender budgeting or to ensure that gender budgeting becomes a regular part of their national budgeting process.

Bridge has highlighted the challenges that developing countries face with budgeting. ${ }^{91}$ Some of the reasons mentioned also have application to the adoption of gender budgeting. The relevant challenges which are of concern to gender budgeting are studied in this section.

One of the major challenges identified is the lack of budget data and socio-economic statistics. ${ }^{92}$ In many developing countries there is no updated gender-disaggregated data which enables budget framers or other relevant stakeholders to assess the impact of their expenditure. ${ }^{93}$ Gender-disaggregated data is imperative for gender budgeting because it is the basis on which the relevant stakeholders assess the policies of the government and its impact on women's human rights. As such, the starting point is the identification of the type of information that is needed to analyse gender budgets and to embark on the collection of such data. This can act as a disincentive for the adoption of gender budgeting.

There is still a lack of accountability and transparency in the budgeting process. ${ }^{94}$ The budgeting process has been categorised as a 'black box' which provides no access to citizens or to those who were not involved in the budgeting process. ${ }^{95}$ Despite the fact that the budgeting process has now become more transparent, there are still limits on the information which is available to the public. ${ }^{96}$ Legislation concerning access to information in budgets is still weak. Furthermore, there are still few female advocates for gender rights and as a result the laws are mostly gender neutral. ${ }^{97}$ The lack of accountability can

\footnotetext{
$91 \quad$ Bridge (n 6o) 11-14.

92 Bridge (n 6o) 11 .

93 Ibid.

94 Bridge (n 6o) 12.

95 Bridge $(\mathrm{n} 60) 11$.

$96 \quad$ Ibid.

97 Bridge (n 6o) 12.
} 
be linked to the poor adoption of gender budgeting since there are no mechanisms available through which stakeholders can request for information to analyse the budget from a gender lens. Moreover, there are certain line items in the budget such as the defence budget that are not made public. The lack of transparency in the budgeting process can act as a challenge to the adoption of gender budgeting since it is impossible to do an accurate analysis of the budget from a gender lens in such a case.

In addition to the above, budgeting processes in some countries are still exclusive of the participation of the public or relevant stakeholders..$^{98}$ This acts as a challenge for the adoption of gender budgeting since gender budgeting assumes that all relevant stakeholders are given the opportunity to participate and to contribute to the process. In some countries where gender budgeting is an initiative of csos, this requires the system to be participatory. csos need to be able to participate in the process and need to obtain information to analyse them and to produce reports which will be considered by the government. The non-participatory nature of the budgeting process in some countries acts as a hindrance for the adoption of gender budgeting.

One of the functions of gender budgeting is to assess the impact and the efficiency of government's expenditure on women's human rights. However, assessing the impact and efficiency of government's expenditure is a complex process. Bridge has highlighted that in most cases the efficiency of government expenditure can be measured only in financial terms without analysing how it has actually empowered women. ${ }^{99}$ For instance, an analysis of the expenditure on reproductive policies can be assessed by looking at sensitisation programs but the programs cannot be indicative of how influential it has been for women. As a result, relevant stakeholders face difficulties in assessing the impact and efficiency of government's expenditure.

Governments often face lack of revenues, inappropriate projections and pressure of multilateral donors during the preparation of the public budget. ${ }^{100}$ The expenditure of the government is dependent on the revenue of the government. Most times the government does have sufficient revenue to adopt gender budgeting since it requires resources. Further, governments might have the political will but the lack of revenue pushes them to adopt social policies which benefit everyone instead of adopting different policies aimed at promoting gender equality. In addition to constraints due to government revenues,

$\begin{array}{ll}98 & \text { Ibid. } \\ 99 & \text { Ibid. } \\ \text { 10o } & \text { Ibid. }\end{array}$


there are also pressures from multilateral donors who require governments to spend the aid received in a manner consistent with the donors' policies.

The last challenge identified by the Bridge report for the adoption of gender budgeting is decentralisation. In a country where there is decentralisation, the budget is prepared at the local level due to the proximity of the implementation of public policies. ${ }^{101}$ The local governments are dependent on the provision of resources from the national government. If the national government does not provide additional funds for the adoption of gender budgeting, it will be difficult for the local governments to adopt policies aimed at reducing gender inequality. Additionally, the previous challenges discussed in relation to the adoption of gender budgeting at the national level apply to the adoption of gender budgeting in local government budgets.

The process of gender budgeting is one that is complex and reliant on several other factors as highlighted in this sub-section. This can act as a disincentive for governments to adopt gender budgets. Nevertheless, governments have committed to allocate resources to realise women's human rights. Furthermore, it has been pointed out that gender budgeting embraces principles of good governance including efficient and effective expenditure. Governments have to realise that development is not possible if women's human rights are still being violated and that they need to address this concern as far as they can and allocate their resources to that means. Finally, gender budgeting enables states to implement their obligations to provide budgetary resources to realise women's human rights as provided by the Maputo Protocol and as such, states have to engage in gender budgeting initiatives.

\section{4 \\ Conclusion}

In a nutshell, despite the fact that African states have ratified the Maputo Protocol, they have still not been able to provide budgetary resources to realise the rights therein. Since gender budgeting takes into account budgetary allocations for the realisation of women's human rights, it can be adopted as a step to implement the budgetary allocation provisions of the Maputo Protocol. The available literature on gender budgeting emphasises the objectives of gender budgeting and the challenges in its implementation. The scholars do not view gender budgeting as a policy which has adverse effects since their criticisms are limited. They rather believe that gender budgeting is a tool which can assist in the realisation of women's human rights once the challenges are overcome.

101 Bridge (n 6o) 13. 
This research relies on the above views to put forward gender budgeting as a means for states to implement their obligation to provide resources to realise women's human rights. It considers gender budgeting as a policy which will favourably influence spending on women's human rights. 